WORKING PAPER \#460

PRINCETON UNIVERSITY

INDUSTRIAL RELATIONS SECTION

DECEMBER 2001

\title{
Ronald Reagan and the Politics of Declining Union Organization*
}

\author{
Henry S. Farber \\ Bruce Western \\ Princeton University \\ Princeton University
}

\begin{abstract}
While research on U.S. union election activity has focused on the declining proportion of union victories, a large share of the decline in new union organizing is due to a fall in the number of elections contested. We examine the level of election activity and find that the number of union elections fell by 50 percent in the early 1980s. A formal model indicates that declining election activity may be due to an unfavorable political climate which significantly raises the costs of organizing, even though the union win-rate remains unaffected. We then relate the timing of declining election activity to two key political events - the airtraffic controllers strike of 1981 and the appointment of the Reagan Labor Board in 1983. Empirical analysis of monthly election time series shows that the sharp fall in union organizing preceded these political developments.
\end{abstract}

*Farber: Industrial Relations Section, Firestone Library, Princeton University, Princeton, NJ 08544-2098. email: farber@princeton.edu. Western: Department of Sociology, 116 Wallace Hall, Princeton University, Princeton NJ 08544-1010. email: western@princeton.edu. This paper was prepared for a conference on Union Growth held at the University of Toronto in honor of Noah Meltz, April 30 - May 1, 2001, and the paper reflects useful comments received at that conference. 
Declining membership in American labor unions through the 1980s is often traced to political causes. Following the national election of 1980, the Republican Party controlled the Senate and union leaders found regular support among just 130 out of 435 representatives in the Democratic-controlled House (Gross 1996, 247). Most important, the incoming Reagan administration boasted a free-market philosophy that was inimical to the interests of organized labor. The frankly anti-union stance of the Reagan administration was expressed in public policy and political appointments.

During the first Reagan administration, two political events stand out as symbolizing vigorous Republican opposition to organized labor. First, in the summer of 1981, striking air-traffic controllers were dismissed by President Reagan and non-union employees were hired as replacements. This event is often held out as demonstrating a new strategy of employer opposition to industrial action. Second, in the twelve months following the election, two seats on the five-seat National Labor Relations Board (NLRB) were filled by Reagan appointments. These and subsequent appointments to the Labor Board were to establish a solid pro-management majority that expanded employers' rights to oppose union organizing.

Earlier research on the political determinants of unionization examined trends in the unionization rate, or the success rate of unions in NLRB elections. Although the Reagan administration is sometimes charged with lowering the overall rate of American union organization, union delcline has a significant structural basis in the slow (even negative) rate of employment growth in unionized sector of the economy relative to the nonunion sector (Farber and Western 2001). The political determinants of unionization are thus more likely to be observed in the process of new union organizing. A number of studies observe that the success rate of unions in NLRB elections has declined through the postwar period Weiler 1983; Lalonde and Meltzer 1991). The slow rate at which unions now organize new members is thus attributed to electoral failure.

Although our analysis studies the organization of new union members, we shift attention from the election win-rate to the overall volume of election activity. The annual number of elections contested by unions fell dramatically in the early 1980s. Although often overlooked, the effect of declining election activity far overshadows the impact of declining electoral success on new union organizing. Using a series of monthly data on election activity, we 
document this decline and examine its timing in relation to the air-traffic controllers' strike and the installation of the Reagan Labor Board. We find that the sharp decline in election activity follows the inauguration fo President Reagan but precedes the air-traffic controllers strike and new appointments to the Labor Board.

\section{Trends in Union EleCtion Activity}

The National Labor Relations Act (NLRA) provides the central mechanism through which jobs become unionized. The NLRA, passed in 1935, guarantees the rights of workers to organize and bargain collectively with their employers. The Act also specifies a procedure for unions to become recognized as the exclusive bargaining agent of workers. The procedure is initiated when a large proportion (at least 30 percent) of workers show interest in union representation by signing authorization cards. The union then petitions the NLRB to conduct a representation election. Employers and unions campaign among workers from the time of the petition until the election. The NLRA also defines a set of unfair labor practices (ULPs) that limits the use of threats, dismissals, and coercion to influence the vote or the organizing process, more generally. Violations can be remedied by bringing ULP charges before the NLRB.

In the early post-NLRA years new union members were often enlisted outside the NLRB election process through the use of "recognition strikes" and "card checks." The meaning of the recognition strikes is self-evident. Organization through card checks occurred when employers agreed, without an election, to recognize a union and bargain following a strong show of interest by workers through signed authorization cards. While systematic evidence on the quantity of organizing through these mechanisms difficult to come by, the general perception is that they have become much less important in new organizing.

\section{The Quantity of Election Activity}

The left-hand plot of figure 1 presents the number of NLRB-supervised representation elections held each year from 1940-1998. The large spurts of election activity in the early 1940s

and early 1950s are clearly evident. Additionally, the number of elections increased rapidly during the 1960s before leveling off in the mid-1970s. This was followed by a sharp decline 

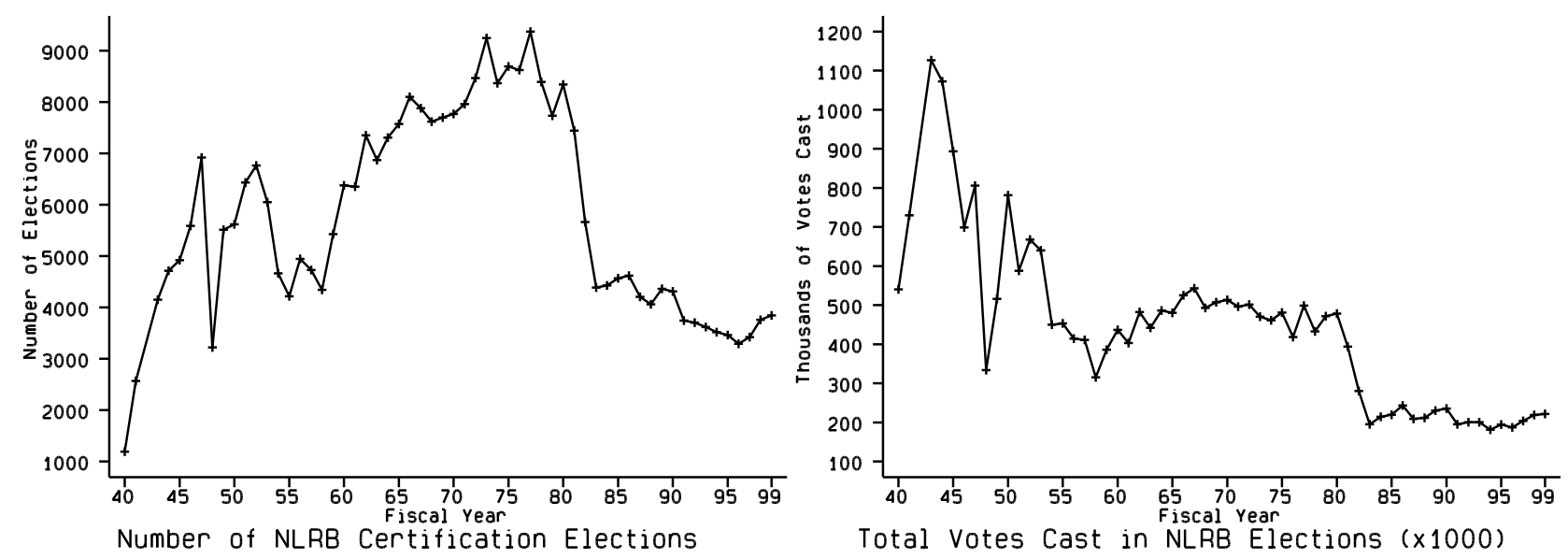

Figure 1: Quantity of NLRB Election Activity, 1940-1999

in the early 1980s. Since 1983, the number of elections has held steady at a relatively low level. The right-hand plot of figure 1 presents the total votes cast in representation elections over the same period. While the spurts are evident in this series, there is a fairly steady decline in the total votes cast from the mid 1940s through the late 1950s. ${ }^{1}$ The level of voting was fairly stable through the 1960s and 1970s before dropping precipitously (along with the number of elections) in the early 1980s. The total votes cast has remained steady at a very low level since the mid-1980s.

Figure 1 strikingly illustrates the sharp decline in union organizing activity in the early 1980s. The number of elections held fell by almost 50 percent from about 8000 in 1980 to about 4400 in 1990 . The number of votes eligible to be cast fell from about 512,000 to about 221,00 over the same period, a drop of over 50 percent. We will return to this later in this section when we discuss the role of changes in administration of the NLRA in the decline of union organizing.

It is interesting that the sharp decline in union election activity in the 1980s was not accompanied by a parallel decline in the proportion of elections won by unions. Figure 2 plots the union win rate in representation elections held between 1940 and $1998 .^{2}$ While

\footnotetext{
1 The difference in time-series behavior between the elections series and the votes series is reflects the fact that the average election size fell over this period.

${ }^{2}$ Farber (1999) presents an analysis of the decline in union success that focuses on the fact that union success fell more sharply in large units than in small units.
} 


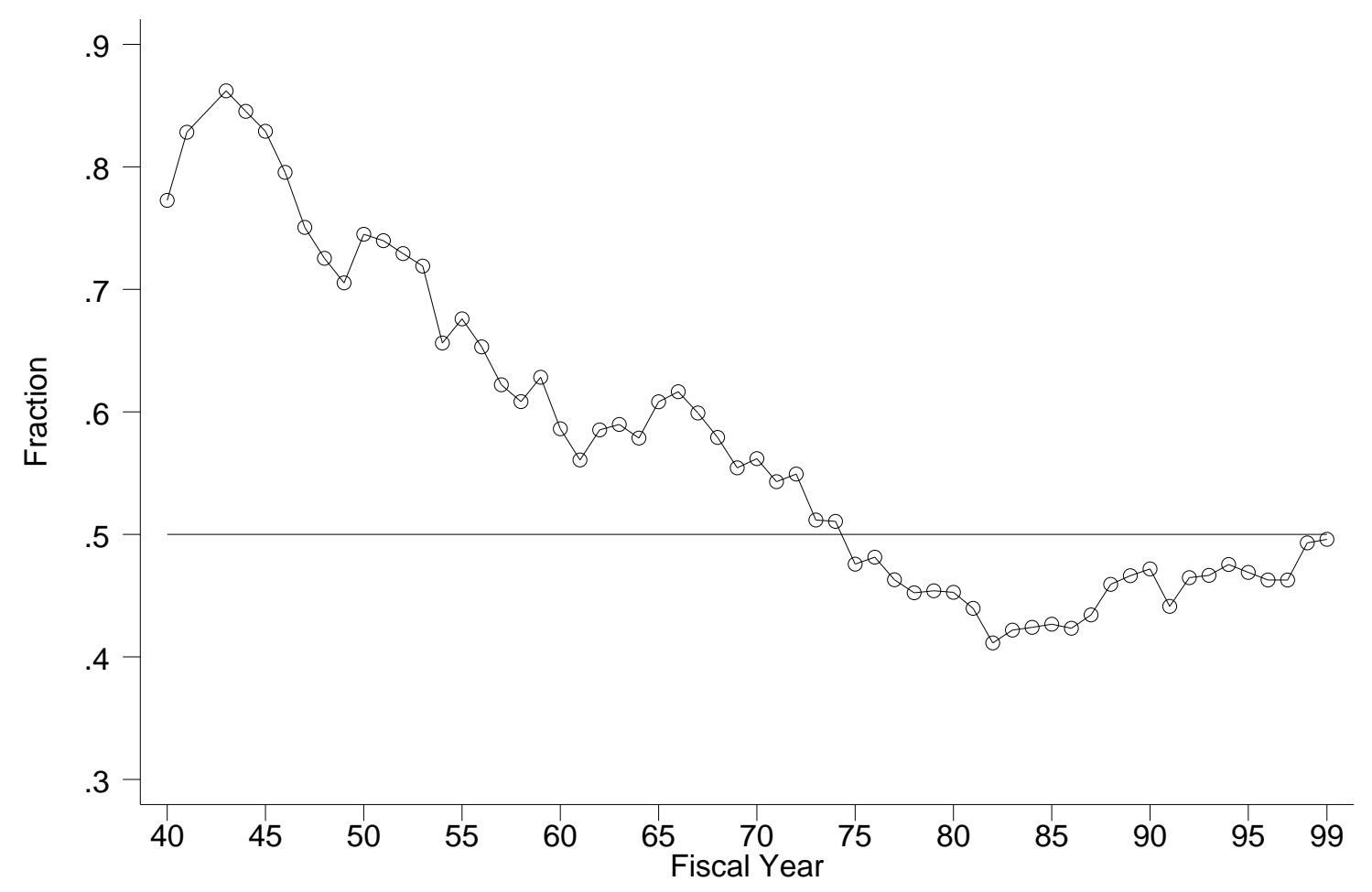

Figure 2: Union Win Rate in NLRB Elections, 1940-1999

the win rate fell sharply between 1940 and 1975, the win rate has held steady since the mid-1970s. In the early 1950s, unions won 72 percent of all representation elections and by the late 1970s the union win rate had dropped to 49 percent. Since then, the union win rate has remained at approximately that level.

An additional factor intervening to reduce the effective amount of new organization is the increased difficulty newly-organized workers have had in negotiating a first contract with employers. While there are no systematic data on representative samples of union-won elections, Weiler (1984) reviews several studies and reports that the fraction of union wins yielding first contracts fell from 86 percent in 1955 to 63 percent in $1980 .^{3}$ Thus, even the already small new-organization rate based on the number of workers in potential bargaining units where unions won elections overstates the number of newly-organized workers.

While the union win-rate and to a lesser degree, the probability of a first contract, have

\footnotetext{
${ }^{3}$ See also, Prosten (1978) and Cooke (1985). The NLRA provides that unions have one year from the date of certification as the bargaining agent of the workers to negotiate a contract. If no contract is negotiated in that time, the union is no longer recognized as the bargaining agent.
} 
received some attention in analyses of union organizing, the massive decline in union election activity and its sharp drop in the early 1980s have gone largely unnoticed. The timing of the decline in election activity - coming in the first years of the Reagan administrationappears to provide support for political accounts of the losses suffered by organized labor in the 1980s.

We next develop a simple model of union election activity that can reconcile the sharp decline in representation election activity during the 1980s with the steady win rate. This model highlights the role that political and economic factors can play in the election process. We then review these political developments, before providing a more detailed analysis of trends in election activity.

\section{A Model of Union Election Activity}

An economically rational labor union will contest elections only where there is a positive expected value associated with the election. By this we mean that the value of a successful organizing effort to the union, including both the benefit to the newly organized workers and the benefit to the union as a whole, adjusted for the likelihood of success outweighs the cost of the election effort. This suggests that among all possible potential bargaining units (firms and establishments), called "targets" here, elections are more likely to be held where the likelihood of a union victory is higher. There are important implications for the analysis of both the quantity of election activity and election outcomes over time. First, the potential bargaining units in which elections are held at any point in time are not representative of the pool of targets since elections are more likely to be held in places where the likelihood of sucess is higher. Second, the pool of these "favorable" targets is likely to become depleted over time as unions win elections in the best targets. This is true 1) even if the likelihood of union victory within particular targets is not changing over time and 2) new targets are being created due to the creation of new firms and the growth of existing firms into new establishments. Thus, independent of any changes in worker or employer attitudes, the quantity of union organizing is likely to decline over time.

An intuitive description of the framework we have in mind to support this assertion starts from an economy without labor unions but where there is latent demand for unions. Starting 
from this point, there is a distribution across firms of predisposition toward labor unions. Over time, unions organize in the targets (firms and establishments) where workers are most predisposed toward unions so that the remaining pool of targets is declining over time in its average predisposition toward unions. New targets are "born" nonunion. If workers in new targets have the same distribution of predisposition toward unions as the in the initial distribution, then the average predisposition toward unions is higher among new targets than among those pre-existing targets that remain nonunion. In this case, new firms and establishments serve to replenish the pool of good targets for unionization, but whether this replenishment is sufficient to offset the depletion of high-quality existing targets depends on the birth rate of new targets relative to the organization rate among existing targets. Alternatively, workers in new targets may be less favorably disposed toward unions than were workers in the inital distribution of firms and establishments. ${ }^{4}$ In this case the pool of targets for new organization is even more likely to be declining in predisposition toward unions over time.

Now consider a union's decision regarding whether or not to contest an election in a specific target at a point in time. We characterize each target in three dimensions:

1. The probability that the union will win an election should one be held. Denote this probability by $\theta_{i}$, where $i$ indexes the target, so that $\theta_{i}$ represents the probability that more than one-half of the voters cast their votes in favor of union representation. ${ }^{5}$

2. The value to the union of organizing the target, including both the value to the workers being organized and to the union as a whole and other members of the union. This value is net of any costs of servicing the members of target $i$ once it is organizied. Denote the net value by $R_{i}$.

3. The cost of the union organizing effort to the union, including the cost to the workers

\footnotetext{
${ }^{4}$ This could result from employers taking the likelihood of union organization into account when siting new firms and establishments. They may try to locate in areas (e.g., the South) where workers are less favorably disposed toward unions and/or the economic, political, and social environment is hostile to unions.

5 There is a status-quo bias built into the election process through the National Labor Relations Act. Unions lose ties in certification elections and unions win ties in decertification elections. Only certification elections are considered here.
} 
being organized. Denote this cost by $C_{i}$.

Define the expected value to the union of contesting an election at target $i$ as

$$
V_{i}=\theta_{i} R_{i}-C_{i}
$$

A rational union will undertake to organize the target if $V_{i}$ is positive. This implies that the condition for an election to be held is

$$
\theta_{i}>\frac{C_{i}}{R_{i}}
$$

The right hand side of equation 0.2 defines a critical value for the probability of a union victory. This is

$$
\theta_{i}^{*}=\frac{C_{i}}{R_{i}}
$$

and unions will contest elections where $\theta_{i}>\theta_{i}^{*}$.

Now consider the effect of a change in the economic, political, or social environment. These can affect any of the three target characteristics, and consider, in turn, changes in each:

1. A change that makes it generally more difficult to organize but keeps workers' voting behavior fixed (i.e., did not change $\theta_{i}$ ) is represented by an increase in the cost of organizing $\left(C_{i}\right)$. This would result in a higher critical value for the probability of a union victory $\left(\theta_{i}^{*}\right)$, and the result will be less union organizing perhaps accompanied by some increase in the union win rate as unions are only willing to attempt organization in more favorable targets.

2. A change that reduces the net benefit to union organizing is represented by a reduction in $R_{i}$. Once again, this would result in a higher critical value for the probability of a union victory $\left(\theta_{i}^{*}\right)$, and the result will be less union organizing perhaps accompanied by some increase in the union win rate as unions are only willing to attempt organization in more favorable targets. A reduction in the net benefit of union organization could result from union difficulty in negotiating improvements in compensation and other conditions of employment, perhaps as a result of increased international competition. Employers' use of striker replacements and other tactics will make it more difficult for unions to negotiate improvements for their members as well. 
3. A change that makes workers less likely to vote in favor of unionization is represented by a reduction in $\theta_{i}$, and this will reduce the quantity of union organizing activity by reducing the set of targets where $\theta_{i}>\theta_{i}^{*}$. There will be no change in the union win rate as the selection rule remains unchanged. A change in $\theta$ can occur for any of a number of reasons. Workers could perceive less benefit from unionization. This could be a result of increased competition in the labor market or of improved treatment by nonunion employers. Increased employer resistence to union organizing activity could discourage workers from voting for union representation.

This model has two implications that are consistent with the facts established in figures 1 and 2. First, the win rate declines over time as the the stock of high-probability targets is depleted by past organization efforts. Second, changes in the economic, political, and social environment have had sharply negative effects on the quantity of elections, while the union win rate in elections held has remained relatively fixed and even increased slightly in recent years. We now examine changes in the political environment in greater detail.

\section{The Legal Context of Union Organizing}

A large research literature argues that labor law has contributed significantly to the postwar decline in U.S. unionization. The main framework for labor law is provided by the National Labor Relations Act (NLRA). The original Act of 1935 was passed to quell industrial unrest and encourage collective bargaining. Through a system of government-run elections, the NLRA created an enforceable procedure for union representation based on majority vote within bargaining units. Employer conduct was tightly regulated during elections, and the use of threats and dismissals to influence the vote was prohibited. Violations could be remedied by bringing unfair labor practice charges before the National Labor Relations Board.

Changes in administration of the labor law allowing stronger employer opposition was viewed as a key determinant of American union decline. The employer opposition account was based on three key observations. First, the probability of a pro-union vote declined between 1945 and 1980 (figure 2). Second and as noted above, even when unions obtained certification their success in obtaining a first contract has fallen over time. Third, the number 
of unfair labor practices charges against employers increased sixfold over this same period (Weiler 1983, 1984).

Many observers have interpreted this evidence as suggesting that employers increasingly adopted illegal tactics to defeat union organizing. Labor law was implicated by failing to protect workers' rights to a fair certification process, free of employer coercion. ${ }^{6}$ Various links in the chain of this argument have received detailed empirical treatment. There is mixed evidence that unfair labor practice charges adversely affect the probability of a union election victory. ${ }^{7}$ There is fairly strong evidence that delays incurred by filing objections to the campaign process are associated with a lower probability of union success. ${ }^{8}$ This has led to calls for expedited procedures where the representation decision would happen within a short time after a petition is filed. This could be done either through an "instant election" or "card-check" as is used in Canada (Flanagan, 1987; Weiler, 1990). Either of these options would limit the opportunity of employers to discourage pro-union sentiment through delay or commission of unfair labor practices. The fact that unions have had increased difficulty translating election victories into first contracts has been used to argue that employers are not "bargaining in good faith" as required by the NLRA. This had led some to propose "first-contract arbitration," a requirement that arbitration be used to decide the terms of a first contract if the parties fail to agree voluntarily (Weiler, 1984).

More recently, a number of legal scholars have claimed that the Reagan-appointed Labor Board of the early 1980s established an "active regulatory constraint" on collective bargaining (Weiler 1990) which "accelerated the decline of unionism" (Gross 1996, 255; see also Levy 1985). Seats on the five-member Labor Board are filled by Presidential nominees, serving five-year terms. Because of the term length, the political complexion of the Board changes slowly. A time line of the composition of the Labor Board shows that a Reagan-appointed

\footnotetext{
${ }^{6}$ See, for example, Freeman (1988), Weiler (1984), and Weiler (1990)

7 See Lalonde and Meltzer (1991). Even analyses of the same data have led to dramatically opposed conclusions. Getman, Goldberg, and Herman (1976) used data on employer behavior and individual votes in a sample representation elections to conclude that unfair labor practices had little influence on individual votes. A reanalysis of these same data by Dickens (1983) reached the opposite conclusion. Dickens found that unfair labor practices by employers substantially reduce the probability of a union election victory despite having a relatively small effect on any individuals vote. Flanagan (1987) reviews this literature.
}

${ }^{8}$ See, for example, Roomkin and Block (1981) and Cooke (1983). 


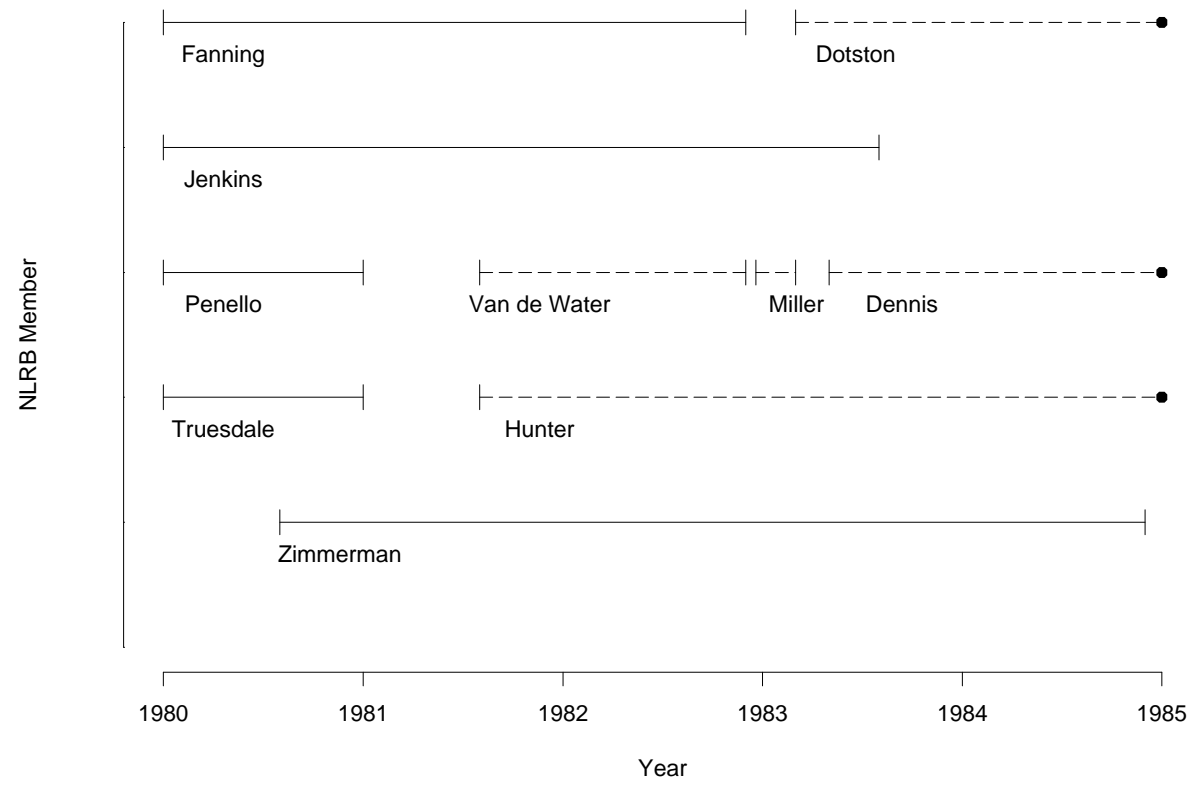

Figure 3: Composition of the NLRB, 1980-1985. Solid lines show Carter appointments; broken lines show Reagan appointments. Fanning, Van deWater, Miller, and Dotson served as chairs.

majority was slow to develop (Figure 3). A few months after Reagan's inauguration in January 1981, Carter appointments Truesdale and Penello stepped down. In August 1981, these openings were filled by President Reagan's first two appointments to the Board, John Van de Water and Robert Hunter. The Carter majority served through 1982, and a Reagan majority was finally formed under the new chairman, Donald Dotson, when Patricia Diaz Dennis joined the Board in May 1983.

The Dotson appointment broke tradition, coming from outside the usual pool of laborrelations professionals supported by business and union representatives (Moe 1987, 268). Dotson, a former steel-industry attorney, brought both a staunchly anti-union stance and an abrasive personal style to the Labor Board. The new chairman attracted controversy, becoming involved in public disputes with other NLRB officals. In addition, while past chairs had relied on the legal resources of the Board's general counsel, Dotson hired as Board solicitor an offical from the National Right to Work Committee - an anti-union lobby group (Gross 1986, 253). 
Critics claim that unions received prejudicial treatment while scrutiny of employer conduct was significantly relaxed under the Dotson Labor Board. Unions faced increased obstacles to contesting elections as representation petitions were increasingly dismissed for failing to specify appropriate bargaining units. Where elections were held, employer conduct was substantially deregulated. Under a line of Dotson Board rulings, employers obtained greater latitude to interrogate union supporters, make misleading campaign statements, speculate about the adverse effects of unionization, and discharge union supporters. In Levy's (1985, 293) review, "The centerpiece of the Board's strategy is to uphold elections marred by unfair labor practices, while legalizing employer practices which interfere with, restrain or coerce employee free choice in elections" (see also Moe 1987, 269). Beyond the election process, employers' obligation to engage in good-faith bargaining was weakened, and employer reprisals against strikers were deregulated. During this time, the Board accumulated its largest ever backlog of unprocessed unfair labor practice claims, delaying elections and first-contract bargaining (Gross 1996; Levy 1985). Dotson vacated his chair of the NLRB in December 1987, and a new chairman, James Stephens, was named in January 1988. Subsequent Labor Boards, although not as activist as the Dotson Board, affirmed the weakened commitment to collective bargaining established during the mid-1980s.

Like research on employer opposition, legal analysis of Reagan's first Labor Board often views union organizing activity as an important cause of union decline. Although the link between unfair labor practices and elections has been studied in detail, the impact of the Reagan Labor Board on quantity of union organizing activity has not been extensively analyzed. A key implication of the legal writing is that the number of elections contested and the union win-rate would both decline under the first Reagan Board. Although the win rate is the focus of earlier research, the major constraint on new organizing (and the variable showing greatest variation over the last 30 years) is the number of elections contested. Of course, as demonstrated by the model presented above, the frequency of elections and the probability of union victory are closely related in the sense that unions will only contest elections they believe they can win.

The influence of Republican administration of the NLRA may be difficult to detect because the industrial relations climate was changing in many ways as Reagan nominees were 
joining the Labor Board. In particular, the air traffic controllers strike of 1981 has been viewed as a key watershed in U.S. labor relations (Northrup 1986; Traynor 1997). Following strike action through the summer of 1981, air traffic controllers were fired by President Reagan and nonunion replacements were hired. The strikers' union, PATCO, lost its representative role, and the hiring of permanent replacements became a highly visible employer strategy for deunionization. Analyses of strike data thus show the high use of permanent replacements in the 1980s in contrast to earlier decades (LeRoy 1995; Wachter and Carter 1989). Traynor (1997) claims that the rate of union wage growth also slowed under the new labor relations regime ushered in by the PATCO strike. Although it chiefly highlighted the role of permanent replacements, the PATCO strike is viewed as initiating a more general employer offensive against labor unions (Shostak 1986; Kochan, Katz, and McKersie 1986). From this perspective, a shift in employer behavior rather than labor law has driven the decline in organizing activity.

It is likely that these changes in the legal and political context of union organizing as well as changes in employer behavior have affected all three characteristics highlighted in the model in ways inimical to union organizing. It is likely that the costs of union organizing $\left(C_{i}\right)$ increased during the $1980 \mathrm{~s}$ while the benefit of union organizing $\left(R_{i}\right)$ has decreased. At the same time, it is likely that the probability of a union win in a typical potential bargaining unit declined during the same period. The result is the sharp drop in union election activity coupled with a slight increase in success in elections held.

We turn now to an examination of the timing of changes in election activity and how they are related to some specific changes in the political and regulatory environment.

\section{Analyzing Trends in Election Activity}

Our analysis studies trends in the monthly count of certification elections, relating these to the PATCO strike and the appointment of the Dotson Labor Board. If the PATCO strike (August 1981) or the appointment of Chairman Dotson (March 1983) influenced organizing activity, we would expect this would result in changes in the trend of the election series around the time of these events. A simple model of this idea fits the election data to a linear spline function with two knots corresponding to each event. In other words, the model fits 
the election data as three connected linear segments, the first and second segments connected at the first knot, and the second and third conneceted at the second knot. The locations of the knots, $\left\{k_{1}, k_{2}\right\}$, are parameters that can be estimated by searching over pairs of monthly time points. Specifying $k_{1}<k_{2}$ restricts the search to unique pairs of knots. Admittedly, this is a rough test because the influence of the Reagan Board grew over time as case law accumulated. Still, the two events provide convenient reference points for summarizing the elections time series.

More formally, the spline function for the count of elections in month $t$ is

$$
\begin{aligned}
e_{t}=a_{0}+a_{1} t+u_{t}, & t=1974(1), 1974(2), \ldots, k_{1} \\
e_{t}=b_{0}+b_{1} t+u_{t}, & t=k_{1}, \ldots, k_{2} \\
e_{t}=c_{0}+c_{1} t+u_{t}, & t=k_{2}, \ldots, 1999(12),
\end{aligned}
$$

where $u_{t}$ is an error term. The six parameters $\left(a_{0}, a_{1}, b_{0}, b_{1}, c_{0}, c_{1}\right)$ must satisfy the pair of constraints that the segments of the spline function meet at the knots. These constraints are that

$$
\begin{aligned}
a_{0}+a_{1} k_{1} & =b_{0}+b_{1} k_{1} \\
b_{0}+b_{1} k_{2} & =c_{0}+c_{1} k_{2}
\end{aligned}
$$

Visual inspection of the series in figure 1 shows a relatively large number of elections in the 1970s, a dramatic drop in election acticity in the early 1980s, and a generally low level of election activity through the 1980s and 1990s. In order to fit the spline function, we use monthly data on the number of elections held in each of the 304 months from January 1974 through June 1999. These data are derived from the election-level data collected by the NLRB. We assume the error follows a normal distribution, and we estimate the change points, $k_{1}$ and $k_{2}$ with likelihood methods using a grid search over the parameter space. If the PATCO strike and the political complexion of the NLRB are fueling a decline in new union organizing, these events should predate our maximum likelihood estimates of $k_{1}$.

Results for the analysis are reported in Figure 4 and the first row of Table 1 . The lefthand panel of Figure 4 shows the monthly number of elections and the regression line from the maximum likelihood esitmate of the spline model. The two vertical lines indicate the 

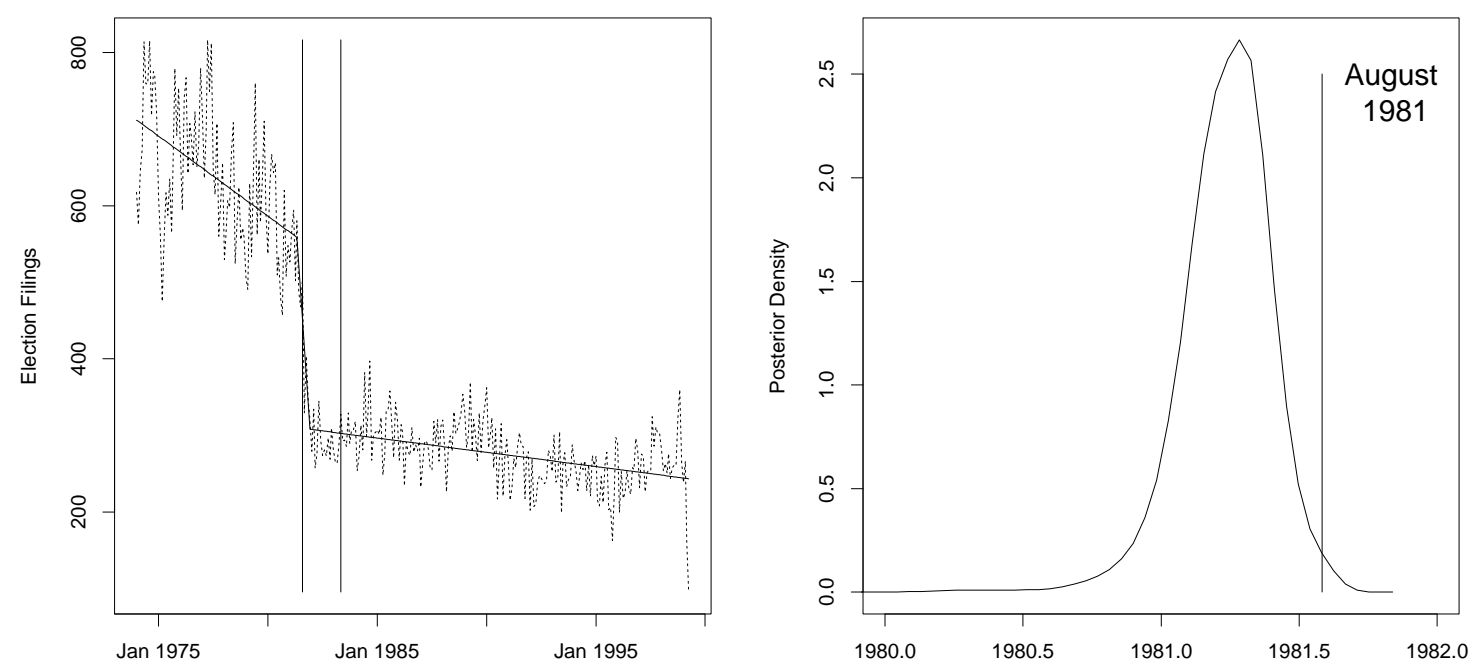

Figure 4: Union elections filed monthly with the NLRB and spline fit, 1974-1999 (left hand side). The vertical lines indicates the PATCO strike and the appointment of the Reagan NLRB. Probability density of the first knot in the spline models (right hand side).

timing of the dismissal of the PATCO air-traffic controllers in 1981 and the formation of a Reagan majority on the NLRB in 1983. Our estimates indicate that the sharp downturn in election activity pre-dates the PATCO strike by a few months. By the time Reagan appointees dominate the Labor Board, union election activity has already fallen from its pre-1981 average by about 50 percent. In short, declining union election activity is set in motion before the two most spectacular political developments in labor relations - the PATCO strike and the Reagan Labor Board.

We can take the analysis a step further by estimating the probability that the earliest discontinuity in the election series arrives after the PATCO strike. We form a marginal distribution of $k_{1}$ by integrating over $k_{2}$, and, after appropriate scaling of the likelihood, we interpret this marginal likelihood as a marginal posterior distribution with a uniform prior 
Table 1. Estimates of first and second discontinuity $\left(k_{1}\right.$, and $\left.k_{2}\right)$ in election filing series, average number of monthly elections, and probability that $k_{1}$ is after August 1981. (Standard errors in parentheses; standard errors for $k_{1}$ and $k_{2}$ are measured in months.)

\begin{tabular}{|c|c|c|c|c|c|}
\hline & $k_{1}$ & $k_{2}$ & $\begin{array}{c}\text { Average } \\
\text { pre- } k_{1}\end{array}$ & $\begin{array}{c}\text { Average } \\
\text { post- } k_{2}\end{array}$ & $\begin{array}{c}\text { Probability } \\
k_{1} \text { after } \\
\text { August, } 1981 \\
\end{array}$ \\
\hline Private sector & $\begin{array}{c}1981(5) \\
(1.9)\end{array}$ & $\begin{array}{c}1981(12) \\
(1.5)\end{array}$ & $\begin{array}{l}636.16 \\
(111.4)\end{array}$ & $\begin{array}{l}276.46 \\
(49.8)\end{array}$ & .00 \\
\hline \multicolumn{6}{|l|}{ Industry } \\
\hline Construction & $\begin{array}{c}1984(12) \\
(7.6)\end{array}$ & $\begin{array}{c}1985(1) \\
(3.26)\end{array}$ & $\begin{array}{l}16.54 \\
(6.06)\end{array}$ & $\begin{array}{l}23.56 \\
(49.5)\end{array}$ & .99 \\
\hline Manufacturing & $\begin{array}{c}1979(12) \\
(2.6)\end{array}$ & $\begin{array}{c}1982(2) \\
(1.6)\end{array}$ & $\begin{array}{l}284.8 \\
(60.9)\end{array}$ & $\begin{array}{c}84.3 \\
(49.6)\end{array}$ & .00 \\
\hline Trans., utilities & $\begin{array}{c}1981(8) \\
(3.6)\end{array}$ & $\begin{array}{c}1981(10) \\
(2.8)\end{array}$ & $\begin{array}{c}77.9 \\
(14.9)\end{array}$ & $\begin{array}{c}44.2 \\
(49.8)\end{array}$ & .00 \\
\hline Trade & $\begin{array}{c}1981(6) \\
(2.4)\end{array}$ & $\begin{array}{c}1982(1) \\
(2.6)\end{array}$ & $\begin{array}{l}127.8 \\
(28.5)\end{array}$ & $\begin{array}{c}43.3 \\
(49.9)\end{array}$ & .04 \\
\hline Services & $\begin{array}{c}1981(5) \\
(2.6)\end{array}$ & $\begin{array}{c}1982(3) \\
(3.6)\end{array}$ & $\begin{array}{l}111.8 \\
(21.5)\end{array}$ & $\begin{array}{c}69.8 \\
(49.7)\end{array}$ & .01 \\
\hline \multicolumn{6}{|l|}{ Occupation } \\
\hline Manual & $\begin{array}{c}1979(11) \\
(2.6)\end{array}$ & $\begin{array}{c}1982(2) \\
(1.6)\end{array}$ & $\begin{array}{l}326.3 \\
(62.2)\end{array}$ & $\begin{array}{l}138.4 \\
(49.6)\end{array}$ & .00 \\
\hline Craft & $\begin{array}{c}1984(12) \\
(4.9)\end{array}$ & $\begin{array}{c}1985(1) \\
(2.9)\end{array}$ & $\begin{array}{l}11.7 \\
(6.0)\end{array}$ & $\begin{array}{c}14.9 \\
(49.5)\end{array}$ & .99 \\
\hline Departmental & $\begin{array}{c}1984(6) \\
(19.7)\end{array}$ & $\begin{array}{c}1984(10) \\
(16.4)\end{array}$ & $\begin{array}{l}23.7 \\
(7.4)\end{array}$ & $\begin{array}{c}18.7 \\
(49.5)\end{array}$ & .79 \\
\hline Prof., technical & $\begin{array}{c}1980(7) \\
(10.0)\end{array}$ & $\begin{array}{c}1985(1) \\
(3.6)\end{array}$ & $\begin{array}{c}35.4 \\
(11.3)\end{array}$ & $\begin{array}{c}10.5 \\
(49.5)\end{array}$ & .17 \\
\hline Truck driver & $\begin{array}{c}1981(5) \\
(2.7)\end{array}$ & $\begin{array}{c}1982(3) \\
(3.5)\end{array}$ & $\begin{array}{c}60.8 \\
(14.7)\end{array}$ & $\begin{array}{c}48.4 \\
(49.70)\end{array}$ & .02 \\
\hline Office, clerical & $\begin{array}{c}1981(3) \\
(1.1)\end{array}$ & $\begin{array}{c}1982(1) \\
(1.6)\end{array}$ & $\begin{array}{c}59.5 \\
(14.0)\end{array}$ & $\begin{array}{c}9.5 \\
(49.9)\end{array}$ & .00 \\
\hline Other & $\begin{array}{c}1981(7) \\
(.3)\end{array}$ & $\begin{array}{c}1981(8) \\
(.3)\end{array}$ & $\begin{array}{l}127.3 \\
(22.3)\end{array}$ & $\begin{array}{c}31.3 \\
(50.7)\end{array}$ & .00 \\
\hline
\end{tabular}


over $k_{1}$ and $k_{2}$. We use this posterior distribution to calculate a probability that the first change point in the series follows the PATCO strike. The probability density for the location of the first knot in the spline model is shown in the right hand panel Figure 4. The vertical line in this figure indicates the timing of the PATCO strike. The probability that the decline in the election series August 1981 is less than .1 percent.

A similar analysis for different industries and occupations is described in Table 1. All industries, except construction, show a substantial decline in election activity around 1981. The decline was particularly large in manufacturing where organizing activity fell from 285 elections per month to just 84 per month. Although this represents a substantial fall in union organizing, the downturn begins in late 1979, before Ronald Reagan's inauguration. In construction, there is evidence that discontinuities in union organizing activity follow the PATCO strike and the installation of the Reagan Labor Board. In this case however, the spline model fits rather poorly, and election activity grows sharply in the late 1980s.

Results are similar for election activity in different occupational categories. The largest occupation, manual employment, provides results strongly consistent with those found for industries. Union organizing drops precipitously in manual employment from 326 to 138 elections per month in the early 1980s. However, the decline begins in late 1979, well before the political developments of the 1980s. Estimates for craft and departmental occupations appear to provide some evidence for breaks in the series after the PATCO strike. Here, however, the election series for these occupational categories are not strongly trended, and the spline model captures random variation. In both these cases, estimated knots in the spline model are found well after the key political events of 1981 and 1984.

The model fit illustrates that $k_{1}$ and $k_{2}$ occur very close in time, providing little evidence for the distinct effects of the air-traffic controllers strike and the Dotson Labor Board on organizing activity. Additionally, these data record the number of elections held in each month. These elections reflect filings for election made, on average, about two months earlier. Thus, it is unlikely that Reagan's treatment of PATCO in August 1981 could have an effect on the number of elections held until approximately October 1981. This strengthens our conclusion that the decline in union organizing activity predates the the public watershed event of labor relations in 1980s. In sum, while the PATCO strike and President Reagan's 
first Labor Board may have contributed to a hostile labor relations climate, we find little evidence that these events sharply reduced union organizing activity. Indeed, the trend to declining organizing activity was already in place before the most visible political offensives against organized labor had begun.

\section{Concluding Remarks}

While there is strong evidence that the PATCO strike and the early Reagan labor Board created a hostile climate for labor unions in the 1980s there is little evidence that these developments precipitated the decline in union election activity. The anti-union climate of industrial relations in the 1980s may well have kept election activity at historically lowlevels, but the decisive downward shift in new union organizing is difficult to reconcile with the timing of political events.

Perhaps more to the point, it is the case that the sharp decline in NLRB election activity in the early 1980s did not have a substantial effect on the fraction of private-sector workers who were unionized in the United States. The private-sector union membership rate (classification error adjusted as described by Farber and Western, 2001) declined from 18.4 percent in 1981 to 7.4 percent in 1998. Had the annual organization rate through NLRB elections held at 0.3 percent of the private-sector nonunion workforce, the level that prevailed prior to the decline in 1981 (rather than fall to about 0.12 percent), the private-sector union membership rate would have fallen from 18.4 percent to 9.7 percent. Thus, only about 20 percent of the decline in the union membership rate between 1981 and 1998 (2.3 of 11 percentage points) can be accounted for by the drop in the new-organization rate since the early 1980s. In fact, if there had been no union organizing through NLRB elections at all since 1972, the union membership rate would have fallen only by an additional 1.7 percentage points.

The fact is that the level of new organization through NLRB elections is inconsequential in increasing the union membership rate or even halting the decline. This is because privatesector employment in the nonunion sector has been growing at an average rate of 2.8 percent per year since 1973 while union employment has been shriking at roughly the same rate (Farber and Western, 2001). While we can (and should) debate the reasons for this disparity in growth rates, it seems clear that the larger economic forces dominate the effects of changes 
in administration of the labor laws. Without some change in the underlying employment growth rates, only a massive increase in union organizing (say by a factor of ten or twenty), much larger than anything contemplated to date, could have a significant effect on the size of the union sector. 


\section{REFERENCES}

Cooke, William N. 1983 "Determinants of the Outcomes of Union Certification Elections." Industrial and Labor Relations Review 36(3): 402-414.

Cooke, William N. 1985. "The Failure to Negotiate First Contracts: Determinants and Policy Implications." Industrial and Labor Relations Review 38(2): 163-178.

Dickens, William T. 1983. "The Effect of Company Campaigns on Certification Elections: 'Law and Reality' Once Again." Industrial and Labor Relations Review 36(4): 560-575.

Farber, Henry S. 2001. "Union Success in Representation Elections: Why Does Unit Size Matter?" Industrial and Labor Relations Review 54: 329-348.

Farber, Henry S. and Bruce Western. 2001. "Accounting for the Decline of Unions in the Private Sector, 1973-1998." Journal of Labor Research 22 (Summer): 459-485.

Flanagan, Robert. 1987. Labor Relations and the Litigation Explosion, Washington, D.C. Brookings Institution.

Freeman, Richard B. 1988 "Contraction and Expansion: The Divergence of Private Sector and Public Sector Unionism in the United States." Journal of Economic Perspectives 2 (Spring): 63-88.

Getman, Julius G., Stephen B. Goldberg, and Jeanne B. Herman. 1976. Union Representation Elections: Law and Reality, New York. Russell Sage Foundation.

Gross, James A. 1995. Broken Promise: The Subversion of U.S. Labor Relations Policy, $1947-1994$.

LaLonde, Robert J. and Bernard D. Meltzer. 1991. "Hard Times for Unions: Another Look at the Significance of Employer Illegalities." University of Chicago Law Review 58:953-1014. 
LeRoy, Michael H. 1995. "The Changing Chracter of STrike Involving Permanent Striker Replacements, 1935-1990." Journal of Labor Research 16:423-37.

Levy, Paul Alan. 1985. "The Unidimensional Perspective of the Reagan Labor Board." Rutger Law Journal 16: 269-390.

Moe, Terry. 1987. "Interests, Institutions, and Positive Theory: The Politics of the NLRB." Studies in American Political Development 2:236-302.

Prosten, Richard. 1978. "The Longest Season: Union Organizing in the Last Decade, a/k/a How Come One Team Has to Play with its Shoelaces Tied Together?" Proceedings of the Thirty-First Annual Meeting of the Industrial Relations Research Association: 240-249.

Roomkin, Myron and Richard N. Block. 1981. "Case Processing Time and the Outcome of Representation Elections." University of Illinois Law Review 1981: 75-97.

Shostak, Arthur B. and David Skocik. 1986. The Air Controllers' Controversy: Lessons From the PATCO Strike, New York. Human Sciences Press.

Traynor, Thomas L. and Rudy H. Fichtenbaum. 1997. "The Impact of Post-PATCO Labor Relations on U.S. Union Wages." Eastern Economic Journal 23:61-72.

Weiler, Paul C. 1983. "Promises to Keep: Securing Workers' Rights Under the NLRA." Harvard Law Review 96:1769-1727.

Weiler, Paul C. 1984. "Striking a New Balance: Freedom of Contract and the Prospects for Union Representation." Harvard Law Review 98:351-420.

Weiler, Paul C. 1990. Governing the Workplace. Cambridge MA: Harvard University Press. 